\title{
DETERMINING THE YIELD AND YIELD COMPONENT INTERACTIONS FOR AUTUMN SOWINGS CHICKPEA (Cicer arietinum L.) VARIETIES IN EASTERN MEDITERRANEAN CONDITIONS
}

\author{
DÜRDANE Mart \\ Eastern Mediterranean Agricultural Research Institute, Adana, Turkey \\ e-mail: durdanemart@yahoo.com
}

\begin{abstract}
This research was carried out to determine the seed yield and the yield component interactions in of some chickpea (Cicer arietinum L.) genotypes under Eastern Mediterranean ecological conditions during 2018. Trials were investigated under winter conditions. The area of the research was located between the geographic latitudes of $36^{0} 51^{\prime} 17.21$ North and $35^{\circ} 20^{\prime} 41.61$ East with an altitude of $23 \mathrm{~m}$.

According to the results of the analyses from this study, the highest and the lowest values are following, 406.07-268 kg/da for the yield, 74 - 61 days for the flowering time, 79.97-66.67 cm for the plant height, 49.47-42.2 $\mathrm{g}$ for the 100-grain weight in the winter sowing conditions.
\end{abstract}

Key words: chickpea, varieties, yield 